The effects of climate change on the geography and timing of human mobility

Jon Barnett and Celia McMichael

School of Geography, The University of Melbourne, 221 Bouverie St, VIC, Australia, 3053.

jbarn@unimelb.edu.au, +61383440819

celia.mcmichael@unimelb.edu.au, +61 383446704 


\section{The effects of climate change on the geography and timing of human mobility}

\section{Abstract}

Human mobility over different distances and time scales has long been associated with environmental change, and the idea of climate change is now affecting movement in new ways. In this paper we discuss three cases from the South Pacific to explain the ways anticipated climate futures are changing mobility in the present. First, we examine village relocation in response to coastal erosion and inundation in Fiji, drawing on our study of the unfolding experience of Narikoso village in Kadavu Province. In contrast to this spatially constrained process of permanent relocation, we examine the spatially extended yet temporally constrained seasonal migrant worker program that aims to support economic development in the Pacific Islands by providing temporary work visas in Australia and New Zealand. Finally, we examine the likely effects of proposed open labour markets as a means to promote climate change adaptation, through a study of the analogous example of Niuean migration to New Zealand which has resulted in both permanent migration and a slow circulation of people between both countries. Across these examples, we highlight emerging and potentially constructive ways in which climate change is altering the spatio-temporal patterns and rhythms of mobility.

Key words: climate change, islands, labour, migration, resettlement, temporality 


\section{Introduction}

An enduring challenge in research on human mobility is to understand it in terms other than the unwanted transgression of national borders. Social scientists who study human mobility understand well the hegemony of this territorial trap in thinking about human movement, which is constantly reproduced by populist politics and the media (Agnew 1994). Such a narrow geopolitical framing obscures the reality of human mobility as a normal practice that is interwoven with the everyday and which generates vastly more benefits than costs to individuals and societies (Bauder 2013, de Haan 1999, Levitt and Jaworksy 2007, Silvey 2004, Olwig 2003).

Graeme Hugo contributed to this objective and sanguine understanding of human movement. As a geographer and social demographer, he also applied himself to understanding the relationship between environmental change and human movement in similar ways (Hugo 1996, 2008a). Hugo did not discount the possibility that climate change may force unwanted and deleterious human movements, including across international borders, but this was far from his primary concern. Rather, he was concerned to understand the ways in which more mundane human movements may be affected by climate change, and how human mobility can be creatively harnessed to facilitate adaptation to climate change; he contextualised this in evidence of existing migration systems and demographic trends (Bardsley and Hugo 2010, Hugo 2011). Inspired by Hugo's spirit of cautious optimism and constructive research on climate change and migration, in this paper we draw on three examples to examine how the idea, anticipation and observation of climate change are changing mobility in the Pacific Islands. 
The Islands of the South Pacific are considered highly vulnerable to climate change, and they are often framed as sites of future - and in some accounts contemporary - catastrophic forced migration (Locke 2009). The summary of the most recent Intergovernmental Panel on Climate Change assessment report concluded with high confidence that there was a "risk of death, injury, ill-health, or disrupted livelihoods" in small island developing states "due to storm surges, coastal flooding, and sea-level rise" (IPCC 2014: 13). These are changes that are known to force migration and given that most communities in most small islands live in the coastal zone, and most livelihoods are dependent on natural resources, the risk that climate change may force migration in the future is high (Nurse et al. 2014). Moreover, given the inseparable bond between Pacific peoples and their lands and seas - from which they derive not just their livelihoods but also their identity and cosmology - such forced movements would have catastrophic psycho-social consequences (Campbell 2014). Nevertheless, estimates of the magnitude and timing of potential forced migrations are highly uncertain given the magnitude and timing of changes in climate, oceans and ecosystems is unclear, and the scope for and benefits of adaptation is highly uncertain (McLean and Kench 2015; Barnett 2017). This does not mean there is no risk, but rather that there is pressing need to avoid the realisation of such impacts through timely and proactive adaptation responses. In this paper we explain that policies that facilitate mobility are key to such responses.

As well as being places highly at risk from climate change, the Pacific Islands are also places where, perhaps more than any other region globally, no aspect of social life is unaffected by human mobility - beginning with the initial settlement of islands through to the transnational networks of kin that sustain so much of contemporary development (Bedford 
and Hugo 2012, Hau'ofa 1994). Our examples provide a basis for reflection on this dissonance between the historical and quotidian experience of mobility as normal in the Pacific Islands, and the repeated construction of climate-induced forced migration as disruptive to island life (and more so to the territorial integrity of countries such as Australia).

We describe highly nuanced relationships between human mobility and climate change in the region, and underscore the range of spatial scales and extended temporalities that are at play. First, we show that it is not only observations of environmental changes that affect human mobility, but that anticipated climate futures change institutional responses that influence mobility in the present. This builds on the recognition that anticipated climate futures can change the present (Brace and Geoghegan 2011, Fincher et al., 2015), including in islands where the imaginary of catastrophic futures undermines the case for sustainable development (Barnett and Adger 2003), can create new identities (Farbotko 2010a), and can lead to self-blame (Rudiak-Gould 2012).

Beyond anticipated climate futures, there are two other temporalities to mobility and climate change in the region that emerge through our examples. First, and most obviously in terms of migration theory, past movements set paths for future movements because people who move initially help reduce the transaction costs and uncertainty of movement for those in their social networks who follow similar migration paths (De Haan 1999, Lucas 2006). Indeed, explaining this process of 'cumulative causation' was one of Hugo's key contributions (Hugo 1981, Massey et al., 1993), and it is very much evident in Pacific Island migration systems (Connell and Conway 2000). Second, human movement occurs at a range of temporal as well as spatial scales; it is these more heterogeneous scalar registers 
that distinguish 'mobility' from 'migration' (Sassen 1998). So, whereas migration is usually taken to be movement by a person across an administrative border of some kind and which lasts for at least a year (Brown and Bean, 2005), human mobility may include shorter term movements, such as daily and seasonal movements of people into cities for work, the movements of tourists within and across countries, or the hypermobility of elites who traverse the planet for work and leisure. Pacific Island migration patterns include diverse of temporal dimensions, ranging from permanent migration to short-term relocation and mobility.

We highlight these diverse temporalities through three cases. First, we examine village relocation in response to coastal erosion and inundation in Fiji, drawing on our study of the unfolding experience of Narikoso village in Kadavu Province. This is a spatially constrained process of (perhaps) permanent village relocation, which contrasts with our second example of the more spatially extensive and temporally constrained seasonal worker program, which aims to support economic development in the Pacific Islands by providing temporary visas for work in Australia and New Zealand. By way of a third contrast, we examine the likely effects of proposed open labour markets as a means to promote adaptation in the South Pacific, by explaining the analogous example of Niuean mobility, which is characterised by both permanent moves and a slow circulation of people between both countries. Across all these examples, we highlight risks as well as opportunities and, as Hugo would highlight, the potential for mobility to ameliorate some of the most damaging social impacts of climate change. 
Mobility has long been key to livelihoods and disaster resilience in the Pacific Islands. Many islands were only settled between $1,000-4,000$ years ago and island people have lived in some very challenging environments (Kirch 2010). The first settlers on atolls for example, would have found no surface water, very shallow soils, and very limited land for cultivation, yet in such environments people have survived through perturbations in climate and sealevel, world wars, slavery, and in some cases nuclear testing (Spennemann 2006, Weisler 2001).

Settlement in the region has been profoundly shaped by climatic conditions; indeed recent evidence suggests the second phase of Polynesian expansion to New Zealand and Easter Island in the Pacific Ocean around 1,000 years was enabled by the medieval climate anomaly which changed wind field patterns and enabled sea-voyaging to even more distant lands (Goodwin et al. 2014). Mobility has always been a central strategy for managing the vagaries of climate, empire and globalisation. The Tonga-Samoa-Fiji trade routes, for example, were important in exchanging food and materials as well as in building social networks for the purposes of assistance in times of food shortages (Couper 1973). Shell currency provided a medium of exchange among diverse populations, and was bound up with intermarriage and trade that assisted people in Melanesia to recover from cyclones (Campbell 1990). In atoll environments, intermarriage and extended kinship networks enabled rights to lands that were distributed across different islands in order to spread risks to any given island population (Hooper 1990, Spennemann 2006).

Human mobility is still central to the sustainable development of many Pacific Islands. The role of migration in sustaining livelihoods in Samoa and Tonga has been extensively studied, with recent estimates suggesting there are more ethnic Samoans and Tongans living in 
metropolitan countries than in their countries of origin, and that their remittances account for approximately $30 \%$ of gross domestic product (GDP) in both countries (Connell 2015). Importantly, these remittances help migrants sustain a right to belong to and return to their traditional lands, and so the prospect of future land losses due to sea-level rise may undermine this land-remittance dynamic. In the meantime, however, the movement of Samoans and Tongans and migrants from other Polynesian islands to the United States, Australia and New Zealand has been described as forming a new, far larger Polynesian triangle, characterised by multidirectional flows of people, money, goods, ideas, skills and culture (Barcham et al. 2009). Migration and remittances also sustain many households in atoll islands, for example seafarers from Kiribati account for approximately 15\% of GDP in Kiribati (Borovnik 2006, Browne and Mineshima, 2007), and up to $75 \%$ of income in remote islands in Tuvalu (Chambers and Chambers 2001, Connell and Brown 2005). These exchanges of people, goods and services support the sustainable development of islands, funding the maintenance of village communal assets such as churches, schools and wells, and contributing to household assets and practices such as rainwater tanks and financial savings (Barnett and Chamberlain 2010, Campbell 2014). They also enable significant transfers to islands in times of crisis, as was well described in the case of expatriate remittances to Samoa in the wake of Cyclone Ofa in 1990 (Paulson 1993).

So, human mobility in the Pacific Islands is not a crisis nor even unusual; it is essential for the sustainability of most island communities. Nor is there anything unusual about human mobility being influenced by changes in environmental conditions, and in the majority of cases such movements in the Pacific Islands have enabled adaptation rather than been an indication of its failure (Campbell and Bedford 2014). Indeed, there are reasons to consider 
that those societies that failed to adapt were those that were relatively more isolated and immobile (Hunt and Lipo 2006). The question of the influence of future climate change on human mobility must be framed by this larger socio-historical context, which demonstrates that for the most part mobility is a form of adaptation to changing social and environmental conditions (Kirch 2002).

Given that it has been historically the case, and given the magnitude of future environmental changes expected in the Pacific Islands due to climate change, it seems very likely that climate change will increase human mobility in the region (Campbell and Bedford 2014). Communities in coasts, deltas and flood plains are particularly at risk, and resettlement inland is a likely response as this has significant historical precedent and contemporary salience (Campbell et al. 2007, McNamara and Des Combes 2015). In the longer term, the absence of higher ground may mean some atoll populations may need to move to other islands or other countries, although there is considerable uncertainty about: the combination of environmental and social pressures that may necessitate this; how adaptation may offset this most undesirable outcome; and the willingness of other countries to accept populations (Barnett 2017). Beyond this, little is known about where and even less about how social and ecological changes may lead households and communities to choose to move. It is becoming increasingly clear, though, that talk of 'experts' in science and policy about the supposed inevitability of forced migration does nothing to help people at risk, and indeed may reify the risk of forced migration in many countries (Barnett 2017). Evidence is therefore more necessary than rhetoric in order to learn from examples of mobility in this era where climate change is a dominant frame that shapes understanding of islands. Our three examples seek to provide such evidence. 


\section{Planned relocation in Narikoso, Fiji}

Planned relocation refers to the systematic relocation of people and assets to areas of lower environmental risk. Planned relocation is identified as a process that can enable climate adaptation, particularly adaptation to slow-onset changes such as sea-level rise (Foresight 2011). Globally, there are few examples of climate-related community relocation, although countries and communities in numerous sites - including for example in USA (Alaska), Kiribati, Vanuatu, Vietnam - are considering and/or initiating planned relocation in response to realised and anticipated climate impacts (de Sherbinin et al 2011, Hino et al. 2017).

Despite the highly publicised and widely circulated notion that low-lying atoll nations such as Tuvalu and Kiribati will need to relocate due to rising seas, Fiji is one of the first Pacific Island nations where low-lying coastal communities are beginning to relocate or to plan for climate-related relocation. In 2005, Fiji's first report to the United Nations Framework Convention on Climate Change (UNFCCC) referred to 'land use policies that encourage settlement away from low-lying coastal areas' as potential climate adaptation strategies (Department of Environment Fiji, 2005: 34). The Government has since identified more than 80 communities that might require "potential relocation" in response to anticipated and realised climate risks (Republic of Fiji 2014: 136-141). The Fiji Climate Change Division, in partnership with other Government Ministries and the German Cooperation Agency (GIZ), are preparing National Climate Change Relocation guidelines. Current relocation planning and activities are underway without the foundation of formal national guidelines and established processes. 
Narikoso, located in the outer island of Ono in Kadavu Province, is one iTaukei coastal village where relocation is being implemented in response to sea-level rise, coastal erosion and inundation. In 2016, the authors conducted research in Narikoso, with the support and insight of local counterparts. The village has 27 households and a fluctuating population of between 95 and 109 people. Villages are widely considered the spiritual and cultural home for iTaukei people because most belong to clan units (mataqali) that are tied to a fixed area of land within which a village is located (Tanner 2007). Nonetheless, iTaukei villages are not isolated or static social systems. In Narikoso, as with other iTaukei villages, mobility and migration are normal practices; village members move to the capital Suva for work and education, a few have worked overseas for the Fijian Military Forces, people from neighbouring villages move there following marriage, and some have family members that have migrated overseas. Further, the ancestors of Narikoso lived in different sites on Ono island, before settling in the current site several generations ago (exact timeframes unknown). Villagers report that these previous moves were a response to inter-family disputes and earlier experiences of coastal erosion.

Narikoso villagers practice (semi)subsistence agriculture and fishing, predominantly production of traditional root crops in nearby mataqali farmland (kava/yaqona, cassava, yams, dalo), honey and livestock (chickens), and harvesting beche de mer (sea cucumbers) which are exported to Hong Kong and distributed to mainland China. Transport from and to Narikoso is limited to boat travel (mostly boats with outboard motors) or footpaths to neighbouring villages and farmland. Narikoso is close to the Great Astrolabe Reef; nearby resorts employ some villagers and purchase small amounts of crops and fish. A few houses have begun to generate income by hosting paying-guests (homestays). 
Villagers report that over the past few decades the shoreline in Narikoso village has receded by approximately 15 metres. During high tide the foundations of properties closest to the sea are inundated, and more extensive flooding occurs during king tides and storm surges (Joliffe 2016; SPC 2014). Accordingly, relocation and retreat represents an adaptive response to current environmental problems. Yet villagers also express concern about their environmental futures and many expect that there is a very high likelihood of ongoing erosion, flooding and storm damage. So, both observation and anticipation of climate risks are changing mobility - specifically planned relocation - in the present.

In early 2012, Narikoso villagers sought assistance from the Government of Fiji to construct a new sea-wall so as to prevent further coastal erosion and flooding. Government representatives, however, proposed relocation as a preferred adaptive strategy. Earthworks for the new village started in mid-2012 on a hillside a few hundred metres inland and were carried out by the Republic of Fiji Military Forces (RFMF). The Office of the Prime Minister initially provided $\$ 200,000 F J D$ (approx. 96,000USD) to support excavations. Since late December 2012, the Narikoso village development committee has consulted with Government Ministries, international donors and non-government organisations (NGOs) seeking further financing to support their relocation. The relocation programme is currently managed and funded through the EU-GIZ “Adapting to Climate Change Sustainable Energy" fund. It is also supported by the Ministry of Foreign Affairs and International Cooperation, the Ministry of Agriculture, the Ministry of iTaukei Affairs, the Mineral Resources Department, the Secretariat of the Pacific Community (SPC), and USAID (SPC 2014). Relocation process entails engagement with institutions across multiple scales from the level of the Village Development Committee to international funding agencies. 
Nonetheless, the actual relocation of Narikoso represents a spatially constrained process of mobility within customary land boundaries. The new relocation site comprises land that belongs to two of the village mataqali. It is expected that relocation within customary land will allow villagers to sustain physical, socio-cultural, ancestral and spiritual ties to their land and resources, while also providing protection from flooding and storm surges. However, problems with the new site include landslides, soil erosion, and siltation and sedimentation along the coastline. These problems are being redressed. Further, the new village site is too small to accommodate every household; extended village boundaries have been agreed and demarcated by the iTaukei Affairs Board. The current plan suggested by GIZ is to initially relocate seven households, all of which are in the so-called Red Zone close to the foreshore, to the new site. While this represents a favourable option in terms of cost-benefit analysis (Joliffe 2016), villagers are highly reluctant to be separated into two sites. They feel that spatial separation of households would undermine the everyday life and socio-cultural integrity of the village. Current plans for phased relocation according to level of exposure to coastal erosion and flooding do not reflect local preference and, accordingly, are being reviewed.

Narikoso villagers have raised funds via their local incomes and remittances (approximately $\$ 15,000 F J D)$ to construct a new spring-fed water system that supplies water to the new site. It is expected to provide the new village site with sufficient water. The annual village day is a notable source of fund raising, where members of each mataqali living elsewhere in Fiji return for feasting and activities and mataqalis compete to see which is able to raise the most funds to support village activities, including the relocation process. This is a clear example of how mobility can support climate adaptation. 
Multi-scalar relationships between individuals, households, mobile community members, Provincial Councils, Government Ministries, and international donors and agencies also contribute momentum to relocation planning and activities. Importantly, political will and policy development at the international, national and provincial council level provide legitimacy to planned relocation at the local level. And the effective leadership of the village head (Turaga ni Koro) has enabled the development of broad consensus among villagers around the adaptive potential and need for relocation. So, multi-scalar institutions provide persuasive power as to the adaptive value of relocation, and influence relocation planning in Narikoso.

Narikoso's relocation represents a specific form of mobility with nuanced spatio-temporal dimensions: spatially, it is a short distance move within customary land that is supported by multi-scalar institutional connections that stretch with and beyond Fiji; temporally, it is permanent move that represents an adaptive response to both current and anticipated climate and environmental risk. Further, relocation is occurring against a socio-cultural background of mobile village life and histories, albeit tethered by a sense of belonging to place and mataqali land. And the global dimensions of climate change are noted, with some villagers pointing out that climate-associated risks in their local environments, lives and futures are the outcome of activities of those in high-income countries. If carefully managed and community-led, relocation can provide an adaptive response to local environmental and climate-related risks: this case study highlights the critical importance of ensuring that people have choices about whether, where, when and for how long to move. 
Trade reforms, decreasing transport costs, and economic globalisation have resulted in an increase in the number of people moving under the auspices of temporary migrant worker programs since the early 1980's (Holgate 2013, Valiani 2013). There are now more temporary migrant workers in developed countries than there are permanent labour migrants (Valiani 2013). This is true in Australia, where there are nearly twice as many migrants on temporary work visas as there are permanent migrants (DIBP 2016), and in New Zealand where there are nearly three times as many people arriving on temporary work visas as there are permanent migrants (MBIE 2016).

Temporary migrant workers have a limited right of residence in their host country, and work for pay for limited periods of residence (Tham et al. 2016). They typically transfer a significant proportion of their wages back to their places of origin, and so contribute to and link the economies of both host and source countries. Governments favour temporary work arrangements: host countries benefit from the effects of migrant workers on production and wages and consumption without incurring the costs of settlement and citizenship rights, while source countries benefit from increased flows of foreign exchange and skills (Hennebry and Preibisch 2012, Valiani 2013, Tham et al. 2016). Temporary migrant workers principally benefit from higher incomes for themselves and their families, but there are often few other benefits: while working they are removed from their families and communities and social protections at home, and most often they do not enjoy the same economic, legal and social protections afforded citizens (Holgate 2013, Reilly 2011, Valiani 2013). Temporary migrant workers are prone to exploitation, and can become trapped in a cycle of temporary work; thus temporary migrant worker programs are contentious, particularly from a rights perspective (Martin 2006, Ruhrs and Martin 2008). Even so-called 
'best practice' models typically fall short of ideal outcomes (Hennebry and Preibisch 2012, Tham et al. 2016).

New Zealand is argued to be closest to achieving best practice in temporary migrant worker policy (Brickenstein 2015; Hugo 2009). Its Recognised Seasonal Employer (RSE) scheme commenced in 2007 and has provided temporary visas for over 57,000 Pacific workers from the Pacific Islands (Bedford et al. 2017). The scheme was designed at the behest of the New Zealand horticultural sector, which had been struggling to address labour shortages. It has a focus on providing workers to boost production in horticulture and more recently viticulture, providing producers with a stable, increasingly skilled, and productive workforce (Bedford et al. 2017). The RSE fulfils many of the requirements for best practice seasonal worker schemes, including because it offers many protections to workers, meets legitimate demands for workers in New Zealand, appears to be well monitored, and can be a pathway to permanent residence in New Zealand (Bedford et al. 2017; Brickenstein 2015).

Australia's Seasonal Worker Program (SWP) commenced in 2009, and in that time has provided temporary visas for over 12,000 workers from the Pacific Islands (Bedford et al. 2017). In its initial years it too was focused on meeting labour shortages in horticultural industries, though Australian growers also have access to tourists on working holidaymaker visas. Rather than being industry-led, the SWP was designed by the Australian government to help support economic development in the Pacific Islands. The program has recently been extended to include workers in the hospitality sector (largely to meet labour shortages in the tourism sector), and to work in Northern Australia to support ambitions and investments to develop that part of the country. This latter initiative provides longer visas (up to 2 years) to workers from Kiribati and Tuvalu, which are North Pacific microstates that 
use Australian dollars as their currency, and which are considered highly vulnerable to climate change.

Neither New Zealand's RSE scheme or Australia's SWP were developed as responses to assist the Pacific Islands to adapt to climate change, though, as noted above, Australia's scheme was designed principally for the benefit of development in the South Pacific region. But the issue of climate change is increasingly coming to bear on both schemes. It dovetails with the longstanding request from Pacific Island Country leaders to open labour markets in Australia and New Zealand; labour migration and climate change adaptation are now tied together in negotiations over the Pacific Agreement on Closer Economic Relations, and in discussions at the Pacific Labour Mobility Annual Meeting (MacLellan and Mares 2006, Millbank 2008, Bedford et al. 2017). Scholars within migration and development policy networks - including Graeme Hugo - also identify seasonal worker schemes as potentially very useful measures to assist the Pacific Islands to adapt to climate change (ADB 2012, Bedford and Hugo 2012, Hugo 2009, Opesekin and MacDermott 2009). There is an anticipatory temporality at play, with the need to adapt to, avoid or reduce anticipated climate impacts in the Pacific influencing present discussions about the design of seasonal worker schemes.

The RSE and SWP have provided temporary work visas to over 70,000 workers from the Pacific Islands in the last 10 years (Bedford et al. 2017). Under both schemes, demand for workers is growing and is largely being met. While much remains to be understood about the benefits of these schemes to workers and their families and communities, and in turn about their contribution to climate adaptation capacities, the existing evidence suggests a positive effect (Bedford et al. 2017). The capacity to adapt to climate change is theorised to 
be a function of financial, human and social capital, for example, and migration has been shown to enhance these in many ways (Barnett and Webber 2010, Adger et al. 2015). So too have the RSE and SWP; for example workers' incomes are higher than they would have been in countries of origin, and a significant proportion of their wages is remitted to support families' consumption, investments in land and tools, social networks and education (Bedford et al. 2017, Gibson and McKenzie 2011, Rohorua et al. 2009). In the longer term, because remittances are tied to people on lands, the potential loss of lands or displacement of people from lands may undermine this remittance behaviour. For now, other benefits include the development of workers' skills through training components of each scheme, and through professional experience in agriculture and horticulture that could significantly improve food security and livelihoods in the Pacific Islands (Dun and Klocker 2017). Nevertheless, the schemes have some costs to workers and their families and communities, including persistent concern about overcharging workers for accommodation (Bedford et al. 2017, Brickenstein 2015, Gibson and McKenzie 2011, Oke 2012).

Both the RSE and SWP could be optimised in at least two key ways if supporting climate change adaptation is to become one of their goals. First, in both schemes, the numbers of seasonal workers from the Pacific Islands is low relative to all workers on temporary visas. This is especially the case in Australia, which, for example, granted 12,593 seasonal work visas to people from the Pacific Islands, and 226,812 working holidaymaker visas in 2014-15 (DIBP 2016). Indeed estimates suggest there are many more illegal workers in Australia's agricultural industries than people on SWP visas (Brickenstein 2015). These illegal workers and working holidaymakers reduce demand for SWP workers in Australia. New Zealand presently limits RSE visas to 10,500 per year, though thus far this limit has not been met. 
Assuming the RSE and SWP can increase capacity to adapt to climate change in the Pacific Islands, their impact will be very limited given the number of visas allocated at present relative to both other (non Pacific Island) worker visas, and to the 9.4 million people living in the Pacific Islands or even the 174,000 people living in the most vulnerable low-lying atoll countries of Kiribati, the Marshall Islands, and Tuvalu (SPC 2017).

A second way in which the RSE and SWP schemes could be optimised to support climate change adaptation in the Pacific Islands is by broadening access to a wider range of countries, including those considered acutely vulnerable for reasons of both poverty and low-lying topography (Opeskin and McDermott. 2009). It is notable that the low-lying and least developed countries of Kiribati and Tuvalu supply very few workers under the RSE and SWP; in $2014-15$, workers comprised only $2.9 \%$ and $0.6 \%$ of workers under these respective schemes (Bedford et al. 2017). Indeed, both schemes reflect the geography of migration in the region, as Samoans and Tongans dominate both regular and seasonal worker flows to both countries. In this way the RSE and SWP are shaped by the cumulative causation effect, with existing migrants helping family members and friends to arrive on seasonal work visas. Conversely, because people from Kiribati and Tuvalu are relatively much less familiar with Australia and New Zealand and have few familial connections, and because seasonal workers must meet some of their own travel costs and these are high relative to incomes, they are far less likely to make use of seasonal worker schemes. The exception to these patterns is Vanuatu, which supplies $47 \%$ of workers to the RSE scheme and $28 \%$ to the SWP, and which is not a country from which there is a well established migration route to Australia and New Zealand. If seasonal worker schemes are to support adaptation in the 
Pacific Islands, greater effort needs to be made to facilitate access to the scheme from other parts of the region.

Both the RSE and the SWP schemes are products of network of relations among multiple actors across the South Pacific region, and over multiple scales of activity (from individuals, households, firms, and governments). Both are well established, with scope for further development and refinement for the purposes of facilitating climate change adaptation in the Pacific Islands, as well as in key sectors in Australia and New Zealand where labour shortages impede adjustment (Productivity Commission 2011). There is a temporality to migrant worker experience, defined by the limit of visas, though with many workers returning each year to work, particularly under the RSE, such that it becomes part of the sustained rhythm of livelihoods in many places in the Pacific. There is also an anticipatory temporality linked to demands for the scheme to better accommodate future climate risks. These seasonal worker schemes demonstrate important ways in which mobility increasingly intersects with climate change, and in ways that can be positive for migrants and the places they come from and move to.

\section{The Niuean transnational community}

In the literature on climate change and migration there is growing consensus that migration is an important way to support adaptation (Adger et al. 2015; Black et al. 2011; McLeman and Smit 2006; Tacoli 2009). Migration can enhance capacity to adapt to climate change as it can increase access to financial resources (through wages and remittances); information (to anticipate climate risks, devise appropriate adaptations, and learn from 
their implementation); social resources (by increasing networking and bonding among people and groups); and can boost human capital (through skills and increasing money to invest in education and training and healthcare) (Barnett and Webber 2010).

Migration is a fundamental freedom that gives people choices about whether, when, and how to adapt.

Freeing restrictions on the movement of people between countries has been therefore argued to be a cost-effective way of facilitating adaptation to climate change, particularly for small island states (Annis 2015; Barnett and Chamberlain 2010; Fornalé 2017; Hugo 2009; Opeskin and MacDermott 2009; Weber 2015). This is of course not to say that the costs of adaptation should all be borne by people in small island states, for it is clearly a principle of the United Nations Framework Convention on Climate Change that developed countries with large emissions are responsible for meeting the costs of adaptation in most vulnerable countries such as those in the South Pacific.

Of course, migration outcomes are not always positive, much depends on the circumstances of movement and reception. Migration generally has positive outcomes where movement is voluntary and in response to opportunities, migrants have marketable skills and social networks, and migrants receive the same rights as host populations (Hammer 1985; Hill et al. 2006; Hugo 2008b). When these circumstances are to degrees lacking, migrants can experience inadequate housing, livelihood insecurity and exploitation, eroded social networks, poor health, and discrimination. So, while in theory unrestricted mobility between island countries and larger metropolitan countries may facilitate climate adaptation, the effects may not always be positive. There are a few natural experiments 
that highlight the consequences of an unregulated migration system, and in the South Pacific one of the best examples is migration from the small island state of Niue.

Niue is a single uplifted coral atoll in the Polynesian triangle of the South West Pacific Ocean. It is served by a twice weekly four-hour flight from Auckland. Politically, Niue is selfgoverning in free association with New Zealand. This means Niueans are New Zealand citizens who hold New Zealand passports and are legally able to enter, live and work in New Zealand and Australia (Barnett 2012). Given their free access to New Zealand, when the international airport opened in Niue 1971 people began to leave in large numbers. Since then, annual population growth on the island has been negative, although the rate of decline has slowed considerably in recent years. At the time of the last census (2011) there were 1,611 people living on Niue of whom 1,317 identified as Niueans (Statistics Niue 2012). A far larger number of people born in Niue live abroad, with the vast majority of these living in New Zealand and in particular Auckland. There are 4,941 people who were born in Niue now living in New Zealand, and a further 18,465 people who identify as being of Niuean descent and who were born in New Zealand (Statistics New Zealand 2013).

From time to time the New Zealand media talks of the demise of Niuean society given the future risks of climate change and the three quarters of the Niuean-born population that do not reside on the island (Barnett 2012). But it no longer makes sense to equate Niuean society with the island of Niue. Niuean society is far more than the sum of people living on the island, as evident by the fact that over 18,000 people elect to identify as Niuean in the New Zealand census even though they were born in New Zealand. There is also a great deal of short term movement in and out of Niue. Niue received 6,214 visitors in 2010, the 
majority of which were expatriate Niueans visiting family and friends (Statistics Niue 2017). Niueans in Niue are also highly mobile, with 1,747 resident Niueans leaving the island in 2009 (the last year for which there is data), mostly for the purposes of visiting friends and relatives abroad (Statistics Niue 2017). Therefore, more than twice the number of Niueans living on the island visit Niue from New Zealand each year, and more than the entire population of the island leaves the island each year, mostly to visit friends and relatives. Furthermore, many Niueans living abroad intend to return at some stage. During fieldwork in Niue the first author of this paper identified over two dozen Niuean residents who had at some stage left the island for several years, and who described their time away as not leaving, but rather as "taking a long time to come home".

There is therefore a churn in Niue's population, with the island itself as a waypoint, and relatively high numbers of people moving in and out of the island on an annual basis, and a smaller number moving away and back over periods of several years. Bedford and colleagues (2006) rightly consider that Niue has an 'effective' population that is far larger than the count of residents on the island at any given time. Niue has a transnational population that has as its core an identity associated with the island, but the majority of which is not resident on the island. It is for all intents and purposes a community, based on a shared sense of identity and which works to support its members economically and socially.

Despite significantly reduced pressure on the island's ecosystems (and so greater ecological resilience in the face of climate change), and higher standards of living, the departure of so many people does create problems for those who remain in Niue. These challenges include: smaller markets and associated problems of monopolies, high prices, and lack of key goods 
and services (such as insurance); a lack of key skills, for example the island usually has no civil engineers, town planners, or surgeons in residence; a political system that seems outdated given it was designed when the population was three times larger; a hyperconcentration of social capital that can stifle social innovation; and very high costs of social reproduction (for example in caring for the elderly and maintaining villages) (Barnett 2012). Yet these problems do not outweigh the benefits for those Niueans who remain on the island, who choose to stay because it provides them with a livelihood, lifestyle and identity that they prefer.

Relative to other New Zealanders, Niueans in New Zealand fare slightly less well: they earn $25 \%$ less, are significantly less likely to own their home, are somewhat less likely to have a formal qualification, and are more than twice as likely to be unemployed (Statistics New Zealand 2013). Nevertheless, Niueans do not remain in New Zealand against their will, they are free (and can afford) to stay, return, or to move on to Australia (which a small but growing number do). They stay because they have better access to work, advanced healthcare, and tertiary education, as well as a wider range of schools, goods, and other services. Niueans in New Zealand have also reported feeling less burdened by the hard work of gardening and fishing, and obligations to church and village that are inherent in life in Niue (Mitchell 1977).

Niue's two populations interact across diverse economies and places in ways that are mutually beneficial. For example, though there are no official data, there is most probably more money sent from Niue to family members in New Zealand, and considerably more goods sent from New Zealand to Niue (Barnett 2008). Niueans in New Zealand wishing to actively identify as Niuean maintain access to families and lands on the island by 
maintaining good relations with their families in Niue and participating in decisions about land management, returning to the island on occasion, and housing relatives visiting the island while in transit or for education, health care, or while on holidays. Through these familial connections (and greatly enabled by their New Zealand citizenship), Niueans in Niue benefit from access to the far wider range of commodities and commercial, education and health services available in New Zealand, while maintaining their quality of life in Niue and their identify as the real custodians of Niuean culture (Barnett 2012).

The Niuean population is therefore a good analogue of the likely effects of free mobility as a strategy to facilitate adaptation to climate change on islands - though noting that Polynesians seem far more likely to leave home than other island cultures. This challenges the trope of 'vulnerable island society', for in Niue's case much of that society no longer resides on an island, and this is to the benefit of those who wish to remain, who have far larger social networks, can draw on a far larger array of services and goods, and have far greater choices about where to live and when to stay and move. Indeed, the lack of options for migration and an associated diaspora contributes to the sense of relatively greater vulnerability to climate change on similarly small islands such as Tuvalu. The case implies that open migration pathways and labour markets between small islands states in the South Pacific and Australia and New Zealand may be a useful way for those wealthier countries to support adaptation to climate change in the region, giving people the freedom and opportunity to stay or leave, or some combination of both over space and time, according to what they perceive is in their best interests.

\section{Conclusions}


Our three examples speak to the diverse spatio-temporalities of migration related to climate change in the South Pacific. They show human mobility across a range of spatial scales (from village relocations over a short distance to moves to distant countries) and moves for different durations (including seemingly permanent moves to new village sites and other countries, multi-year circular migration, moves for seasonal work purposes, and more dynamic mobilities that bind transnational societies.) They also illustrate that mobility in the South Pacific is changing in response to observed as well as anticipated climate impacts.

Our examples resonate with Graeme Hugo's emergent thinking that mobility is one of the more creative, proactive and agency-based forms of response to climate change. As he stated, 'the impacts of climate change will add to already increasing levels and complexity of population mobility.... it is possible to not only cope with those changes but also to harness that population mobility to reduce poverty and enhance economic and social development' (2011: S32). If supported by good governance, enabling policies and programmes and appropriate funding mechanisms, mobility and migration are likely to be more effective in facilitating adaptation than top-down aid-driven process. The examples discussed in this paper suggest people will adapt best when given choices about mobility, and that these choices are enabled by rights, for example to land, to migrate, to equal and fair treatment as workers, and to citizenship. Policies informed by the principle of enhancing choices can efficiently leverage mobility practices and intentions to promote climate change adaptation (Barnett and Adger 2018).

The case studies suggest that given choices about whether to stay or leave for various periods of time, and about where and when to move, people use mobility to maximise the benefits and minimise the risks posed by climate change. They also suggest that perhaps the 
most important issue concerning climate change and mobility in the South Pacific is therefore not if, how many, or where, but rather when, and under what circumstances people will move? Thus, the policy challenge is to expand the choices that people in the region have: to stay - through urgent international greenhouse gas mitigation and support for in situ adaptation; to relocate - through policies that ensure equitable and communityled decisions; and to leave and to return - though migration laws and policies that foster opportunities for seasonal work, or for open borders.

\section{References}

ADB (Asian Development Bank). (2012). Addressing Climate Change and Migration in Asia and the Pacific. Manila: Asian Development Bank.

Adger, N., Pulhin, J., Barnett, J., Dabelko, G., Hovelsrud, G., Levy, M., et al. (2014). Human security. In C. Field, V. Barros, D. Dokken, K. Mach, M. Mastrandrea, T. Bilir, et al. (Eds.), Climate Change 2014: Impacts, Adaptation, and Vulnerability. Contribution of Working Group II to the Fifth Assessment Report of the Intergovernmental Panel on Climate Change (pp. 755-791). Cambridge: Cambridge University Press.

Agnew, J. (1994). The territorial trap: the geographical assumptions of international relations theory. Review of International Political Economy, 1(1), 53-80.

Annis, E. (2015). Climate Change and Trade in the Pacific Island Countries: The Pacer Plus Agreement. Georgetown Journal of International Law, 47, 1497-1520.

Baldwin, A. (2014). Pluralising climate change and migration: an argument in favour of open futures. Geography Compass, 8(8), 516-528. 
Barcham, M., Scheyvens, R., Overton, J. (2009). New Polynesian triangle: Rethinking

Polynesian migration and development in the Pacific. Asia Pacific Viewpoint, 50(3), $322-337$.

Bardsley, D.K., Hugo, G.J. (2010). Migration and climate change: examining thresholds of change to guide effective adaptation decision-making. Population and Environment, 32(2-3), 238-262.

Barnett, J. (2008). The Effect of Aid on Capacity to Adapt to Climate Change: Insights from Niue. Political Science, 60(1), 31-47.

Barnett, J. (2012). On The Risks of Engineering Mobility to Reduce Vulnerability to Climate Change: Insights From a Small Island State. In K. Hastrup and K. Fog-Olwig, (Eds.), Climate Change and Human Mobility: Global Challenges to the Social Sciences (pp. 169-189). Cambridge: Cambridge University Press.

Barnett, J. (2017). The dilemmas of normalising losses from climate change: Towards hope for Pacific atoll countries. Asia Pacific Viewpoint, 58(1), 3-13.

Barnett, J., Adger, N. (2003). Climate change and atoll countries. Climatic Change 61(3), 321-37.

Barnett, J., Adger, N. (2018). Mobile worlds: choice at the intersection of demographic and environmental change. Annual Review of Environment and Resources 43, in press.

Barnett, J., Chamberlain, N. (2010). Migration as Climate Change Adaptation: Implications for the Pacific. In B. Burson (Ed.). Climate Change and Migration: South Pacific Perspectives (pp. 51-60). Wellington: Institute of Policy Studies. 
Barnett, J., Webber, M. (2010). Accommodating Migration to Promote Adaptation to Climate Change, World Bank Policy Research Working Paper 5270. Washington: The World Bank.

Bauder, H. (2013). Nation, 'migration' and critical practice. Area, 45(1), 56-62.

Bedford, R., Poot, J., Ryan, T. (2006). Niue: Population Policy Scoping Study. Hamilton: Population Studies Centre, University of Waikato.

Bedford, R., Hugo, G. (2012). Population movement in the Pacific: A perspective on future prospects. Wellington: Department of Labour.

Bedford, R., Bedford, C., Wall, J., Young, M. (2017). Managed temporary labour migration of Pacific Islanders to Australia and New Zealand in the early twenty-first century. Australian Geographer, 48(1), 37-57.

Black, R., Bennett, S.R., Thomas, S.M., Beddington, J.R. (2011). Climate change: Migration as adaptation. Nature, 478(7370), 447-449.

Borovnik, M. (2006). Working overseas: Seafarers' remittances and their distribution in Kiribati. Asia Pacific Viewpoint, 47(1), 151-161.

Brace, C., Geoghegan. H. (2011). Human geographies of climate change: Landscape, temporality, and lay knowledges. Progress in Human Geography 35(3), 284-302.

Brickenstein, C. (2015). Impact assessment of seasonal labour migration in Australia and New Zealand: A win-win situation? Asian and Pacific Migration Journal, 24(1), 107-129.

Brown, S., Bean, F. (2005). International migration. In D.L. Poston and M. Micklin (Eds.) Handbook of Population (pp. 347-382). Dordrecht, Netherlands: Kluwer.

Browne, C., Mineshima, A. (2007) Remittances in the Pacific Region. Working Paper 
WP/07/35. Washington DC: International Monetary Fund.

Campbell, J.R. (1990). Disasters and development in historical context: Tropical cyclone response in the Banks Islands, Northern Vanuatu. International Journal of Mass Emergencies and Disasters, 8(3), 401-424.

Campbell, J.R. (2014). Climate-change migration in the Pacific. The contemporary Pacific, 26(1), 1-28.

Campbell, J. and Bedford, R., (2014). Migration and climate change in Oceania. In People on the Move in a Changing Climate (pp. 177-204). Netherlands: Springer.

Campbell, J.R., Goldsmith, M., Koshy, K., (2007). Community relocation as an option for adaptation to the effects of climate change and climate variability in Pacific Island Countries (PICs). Asia-Pacific Network for Global Change Research.

Chambers, K. and Chambers, A. (2001). Unity of Heart, Culture and Change in a Polynesian Atoll Society. Prospect Heights: Waveland Press.

Connell, J., and Brown, R. (2005). Remittances in the Pacific: an overview. Manila: Asian Development Bank.

Connell, J. (2015). Samoa and Tonga: Migration and Remittances in the Twenty-first Century. In W.J. Khonje (Ed.) Migration and Development: Perspectives from Small States (pp.122-185). Commonwealth Secretariat.

Connell, J. and Conway, D. (2000). Migration and remittances in island microstates: a comparative perspective on the South Pacific and the Caribbean. International Journal of Urban and Regional Research, 24(1), 52-78. 
Couper, A.D. (1973). Islanders at sea: change and the maritime economies of the Pacific. In H.C. Brookfield (Ed.). The Pacific in Transition: geographical perspectives on adaption and change. London: Edward Arnold.

de Haan, A. (1999). Livelihoods and poverty: the role of migration - a critical review of the migration literature. Journal of Development Studies, 36(2), 1-31.

Department of Environment Fiji, (2005). Climate Change: the Fiji Islands Response Fiji's First National Communication Under the UNFCCC. Government of the Fiji Islands. Available via: http://unfccc.int/resource/docs/natc/fjinc1.pdf

de Sherbinin, A., Castro, M., Gemenne, F., Cernea, M.M., Adamo, S., Fearnside, P.M. et al., (2011). Preparing for Resettlement Associated with Climate Change. Science 334(6055), 456-457.

DIBP (Department of Immigration and Border Protection). (2016). Australia's Migration Trends 2014-2015. Canberra: Commonwealth of Australia.

Dun, O., Klocker, N. (2017). The migration of horticultural knowledge: Pacific Island seasonal workers in rural Australia - a missed opportunity? Australian Geographer, 48(1), 2736.

Farbotko, C. (2010). "The global warming clock is ticking so see these places while you can": Voyeuristic tourism and model environmental citizens on Tuvalu's disappearing islands. Singapore Journal of Tropical Geography, 31(2), 224-38.

Fincher, R., Barnett, J., Graham, S. (2015). Temporalities in adaptation to sea-level rise. Annals of the Association of American Geographers, 105(2), 263-273 
Fornalé, E., (2017). Labour mobility options as adaptation strategies to environmental changes? In Manou, D., Baldwin, A., Cubie, D., Mihr, A. and Thorp, T. (eds.) Climate Change, Migration and Human Rights: Law and Policy Perspectives (pp. 45-67). London: Routledge.

Foresight, (2011). Migration and global environmental change: final project report. London: The Government Office for Science.

Gibson, J., McKenzie, D. (2011). Australia's PSWPS: Development impacts in the first two years. Asia Pacific Viewpoint, 52(3), 361-370.

Goodwin, I.D., Browning, S.A. and Anderson, A.J., (2014). Climate windows for Polynesian voyaging to New Zealand and Easter Island. Proceedings of the National Academy of Sciences, 111(41), 14716-14721.

Hammar, T. (ed.) (1985). European Immigration Policy: A Comparative Study. Cambridge: Cambridge University Press.

Hau'ofa, E., (1994). Our sea of islands. The Contemporary Pacific, pp.148-161.

Hennebry, J., Preibisch, K. (2012). A model for managed migration? Re-examining Best Practices in Canada's Seasonal Agricultural Worker Program. International Migration, 50(S1), 19-40.

Hill, R., Diener, K., Miller, S., White, T. (2006). IDP livelihoods and personal security: case studies from Colombia and Sudan. Refugee Survey Quarterly, 25(2), 40-57.

Hino, M., Field, C.B., Mach, K., (2017). Managed retreat as a response to natural hazard risk. Nature Climate Change. DOI: 10.1038/NCLIMATE3252 
Holgate, J. (2013). Temporary migrant workers and labor organization. In I. Ness (Ed.). The Encyclopedia of Global Human Migration, Oxford: Blackwell.

Hooper, A. (1990). Tokelau. In Ministry for the Environment (Ed.), Climatic change: Impacts on New Zealand, (pp. 210-214). Wellington: New Zealand Ministry for the Environment.

Hugo, G. (1981). Village-community ties village norms and ethnic and social networks: a review of evidence from the third world. New York: Pergamon Press.

Hugo, G. (1996). Environmental concerns and international migration. International Migration Review, 105-131.

Hugo, G. (2008a). Migration, development and environment. Geneva: International Organization for Migration.

Hugo, G. (2008b). Immigrant settlement outside of Australia's capital cities. Population, Space and Place, 14(6), 553-571.

Hugo, G. (2009). Best practice in temporary labour migration for development: A perspective from Asia and the Pacific. International Migration, 47(5), 23-74.

Hugo, G. (2011). Future demographic change and its interactions with migration and climate change. Global Environmental Change, 21, S21-S33.

Hunt, T.L., Lipo, C.P. (2006). Late colonization of Easter Island. Science, 311(5767), 16031606.

IPCC. (2014). Summary for Policymakers. In C. Field., V. Barros., D. Dokken., K. Mach., M. Mastrandrea, T. Bilir., M. Chatterjee., K. Ebi., Y. Estrada., R. Genova., B. Girma., E. Kissel., A.N Levy., S. MacCracken., P. Mastrandrea, and L. White (eds.). Climate Change 
2014: Impacts, Adaptation, and Vulnerability. Part A: Global and Sectoral Aspects. Contribution of Working Group II to the Fifth Assessment Report of the Intergovernmental Panel on Climate Change. Cambridge University Press, Cambridge, United Kingdom and New York, NY, USA, pp. 1-32.

Joliffe, J., (2016). Narikoso relocation project: a cost-benefit analysis of 'hard' adaptation options. Unpublished report.

Kirch, P. (2002). On the road of the winds: an archaeological history of the Pacific Islands before European contact. Berkeley: University of California Press.

Kirch, P. (2010). Peopling of the Pacific: A holistic anthropological perspective. Annual Review of Anthropology, 39, 131-148.

Levitt, P., Jaworsky, B.N. (2007). Transnational migration studies: Past developments and future trends. Annual Review of Sociology, 33, 129-156.

Locke, J. (2009). Climate change-induced migration in the Pacific Region: sudden crisis and long-term developments. The Geographical Journal, 175(3), 171-180.

Lucas, R. (2006). Migration and economic development in Africa: a review of evidence. Journal of African Economies, 15(2), 337-395.

Maclellan, N., Mares, P, (2006). Labour Mobility in the Pacific: Creating seasonal work programs in Australia. In S. Firth (Ed.). Globalization and Governance in the Pacific Islands (pp. 137-171). Canberra: ANU E Press.

Martin, P. (2006), Managing labor migration: Temporary worker programmes for the 21st century. In International Symposium on International Migration and Development. 
Italy: Population Division, Department of Economic and Social Affairs United Nations Secretariat Turin.

Massey, D., Arango, J., Hugo, G., Kouaouci, A., Pellegrino, A., Taylor, J. (1993). Theories of international migration: a review and appraisal. Population and Development Review, 19(3), 431-466.

MBIE (Ministry of Business, Innovation and Employment). (2016). Migration Trends 2015/2016. Wellington: New Zealand Government.

McAdam, J., Burson, B., Kälin, W., Weerasinghe, S. (2016). International Law and Sea-Level Rise: Forced Migration and Human Rights. Fridtjof Nansen Institute Report 1/2016, Lysaker.

McLean, R. and P. Kench (2015) Destruction or persistence of coral atoll islands in the face of 20th and 21st century sea-level rise? Wiley Interdisciplinary Reviews: Climate Change 6(5): 445-463.

McLeman, R., Smit, B., (2006). Migration as an adaptation to climate change. Climatic Change, 76(1-2), 31-53.

McNamara, K.E., Des Combes, H.J. (2015). Planning for community relocations due to climate change in Fiji. International Journal of Disaster Risk Science, 6(3), 315-319.

Millbank, A. (2008). Guest workers for Australia: win-win, token gesture or moral hazard? People and Place, 16(3), 58-67.

Mitchell, G. (1977). Village Agriculture in Niue: An Examination of Factors Influencing Participation and Productivity. PhD. Thesis, University of Canterbury. 
Nurse, L., McLean, R., Agard, J., Briguglio, L., Duvat-Magnan, V., Pelesikoti, N., Tompkins, E. and Webb, A. (2014). Small islands. In C. Field., V. Barros., D. Dokken., K. Mach., M. Mastrandrea, T. Bilir., M. Chatterjee., K. Ebi., Y. Estrada., R. Genova., B. Girma., E. Kissel., A.N Levy., S. MacCracken., P. Mastrandrea, and L. White (eds.). Climate Change 2014: Impacts, Adaptation, and Vulnerability. Part A: Global and Sectoral Aspects. Contribution of Working Group II to the Fifth Assessment Report of the Intergovernmental Panel on Climate Change. Cambridge University Press, Cambridge, United Kingdom and New York, NY, USA, pp. 1613-1654.

Oke, N. (2012). Temporary migration, transnational politics? The politics of temporary migration in Australia. Journal of Intercultural Studies, 33(1), 85-101.

Olwig, K.F., (2003). "Transnational" Socio-Cultural Systems and Ethnographic Research: Views from an Extended Field Site. International Migration Review, 37(3), 787-811. Opeskin, B., MacDermott, T. (2009). Resources, population and migration in the Pacific: Connecting islands and rim. Asia Pacific Viewpoint, 50(3), 353-373.

Paulson, D.D. (1993) Hurricane hazard in Western Samoa. Geographical Review, 83(1), 4353.

Productivity Commission. (2011). Barriers to Effective Climate Change Adaptation. Productivity Commission Issues Paper. Commonwealth of Australia, Melbourne.

Reilly, A. (2011). The ethics of seasonal labour migration. Griffith Law Review, 20(1), 127152.

Republic of Fiji, (2014). Second national communication to the United Nations Framework Convention on Climate Change. Suva, Fiji: Ministry of Foreign Affairs. 
Rohorua, H., Gibson, J., McKenzie, D., Martinez, P.G. (2009). How do Pacific Island Households and Communities Cope with Seasonally Absent Members? Pacific Economic Bulletin, 24(3), 19-38.

Rudiak-Gould, P. (2012). Promiscuous corroboration and climate change translation: A case study from the Marshall Islands. Global Environmental Change, 22(1), 46- 54

Ruhs, M., Martin, P. (2008). Numbers vs. Rights: Trade-Offs and Guest Worker Programs. International Migration Review, 42(1), 249-265.

Sassen, S. (1999). Globalization and its discontents: Essays on the new mobility of people and money. New York: New Press.

Silvey, R. (2004). Power, difference and mobility: feminist advances in migration studies. Progress in Human Geography, 28(4), 490-506.

SPC (Secretariat of the Pacific Community), (2014). Narikoso villagers elated with first harvest since planned relocation. Secretariat of the Pacific Community (SPC). Available at: https://reliefweb.int/report/fiji/narikoso-villagers-elated-first-harvest-plannedrelocation Accessed 28 November 2017.

SPC (Secretariat of the Pacific Community), (2017). Population Projections by PIC. Available via: https://prism.spc.int Accessed November 242017.

Spennemann, D. (2006). Freshwater lens, settlement patterns, resource use and connectivity in the Marshall Islands. Transforming Cultures eJournal, 1(2).

Statistics New Zealand. (2013). 2013 Census. Available via: www.stats.govt.nz/Census/2013census.aspx 
Statistics Niue. (2012). Niue Census of Population and Households 2011. Government of Niue and Secretariat of the Pacific Community, Alofi and Noumea.

Tacoli, C. (2009). Crisis or adaptation? Migration and climate change in a context of high mobility. Environment and Urbanization, 21(2), 513-525.

Tanner, A. (2007). On Understanding Too Quickly: Colonial and Postcolonial Misrepresentation of Indigenous Fijian Land Tenure. Human Organization, 66(1), 6977.

Tham, J., Campbell, I., Boese, M. (2016). Why Is Labour Protection for Temporary Migrant Workers So Fraught?, In J. Howe and R. Owens (Eds.). Temporary Labour Migration in the Global Era: The Regulatory Changes. London: Hart.

Valiani, S. (2013). Temporary migrant, globalization, $20^{\text {th }}$ century to present. In Ness, I. (ed.). The Encyclopedia of Global Human Migration, Blackwell, Oxford.

Weber, E. (2015). Envisioning South-South relations in the fields of environmental change and migration in the Pacific Islands - past, present and futures, Bandung: Journal of the Global South, 2(1), 6.

Weisler, M.I. (2001). Life on the edge: prehistoric settlement and economy on Utrōk Atoll, northern Marshall Islands. Archaeology in Oceania, 36(3), 109-133. 


\section{University Library}

\section{- M M N E R VA A gateway to Melbourne's research publications}

Minerva Access is the Institutional Repository of The University of Melbourne

Author/s:

Barnett, J;McMichael, C

Title:

The effects of climate change on the geography and timing of human mobility

Date:

2018-06-01

Citation:

Barnett, J. \& McMichael, C. (2018). The effects of climate change on the geography and timing of human mobility. POPULATION AND ENVIRONMENT, 39 (4), pp.339-356. https:// doi.org/10.1007/s11111-018-0295-5.

Persistent Link:

http://hdl.handle.net/11343/282633 